WAHANA

AKUNTANSI

Jumalliming
JURNAL ILMIAH WAHANA AKUNTANSI

Vol 13 (2) 2018, 110-128

http://journal.unj.ac.id/unj/index.php/wahana-akuntansi

\title{
ANALISIS PENGARUH PENDIDIKAN DAN PELATIHAN, PENGALAMAN KERJA SERTA PEMANFAATAN TEKNOLOGI INFORMASI TERHADAP KUALITAS LAPORAN KEUANGAN PEMERINTAH DAERAH (Studi Kasus Pada Pemerintah Kota Depok)
}

Vinne Shabrina Budiono*

Muchlis

Indah Masri

Universitas Pancasila

\section{Article Info}

Kata Kunci:

Pendidikan dan Pelatihan; Pengalaman

Kerja; Pemanfaatan Teknologi

Informasi; Kualitas Laporan Keuangan

Pemerintah Daerah.

\begin{abstract}
Abstrak
Tujuan penelitian ini adalah untuk mengetahui pengaruh pendidikan dan pelatihan, pengalaman kerja Serta pemanfaatan teknologi informasi terhadap kualitas laporan keuangan daerah. Penelitian ini menggunakan data primer yaitu kuesioner. Kuesioner disebar sebanyak 60 dan kembali sebanyak 55 kuesioner. Responden yang mengisi kuesioner tersebut adalah pegawai pengelola keuangan Pemerintah Kota Depok. Teknik analisis data menggunakan analisis regresi linear berganda. Hasil penelititan menunjukan bahwa pendidikan dan pelatihan tidak berpengaruh signifikan terhadap kualitas laporan keuangan daerah, pengalaman kerja tidak berpengaruh signifikan terhadap kualitas laporan keuangan daerah. Sedangkan pemanfaatan teknologi informasi berpengaruh positif dan signifikan terhadap kualitas laporan keuangan daerah.
\end{abstract}

\section{How to Cite:}

Budiono, Vinne Shabrina, Muchlis, dan Indah Masri. (2018). Analisis Pengaruh Pendidikan dan Pelatihan, Pengalaman Kerja serta Pemanfaatan Teknologi Informasi terhadap Kualitas Laporan Keuangan Pemerintah Daerah (Studi Kasus Pada Pemerintah Kota Depok). Jurnal Ilmiah Wahana Akuntansi, 13(2), 110-128. https:// doi.org/10.21009/wahana.013.2.2

* Corresponding Author: 


\section{PENDAHULUAN}

Seiring perkembangan Akuntansi Sektor Publik di Indonesia, maka kebutuhan akan akuntabilitas sebagai wujud pertanggungjawaban kepada masyarakat atas kinerja pemerintah menjadi suatu tuntutan yang umum. Menguatnya tuntutan tersebut mengharuskan lembaga pemerintah memberikan informasi atas aktivitas dan kinerjanya kepada publik.

Sebagai wujud pertanggungjawaban tersebut, upaya yang dapat dilakukan adalah dengan menyampaikan pertanggungjawaban berupa laporan keuangan. Hal ini diatur dalam UndangUndang Nomor 17 Tahun 2003 tentang Keuangan Negara dan Undang-Undang Nomor 32 Tahun 2004 tentang Pemerintahan Daerah. Upaya yang nyata untuk mewujudkan transparansi dan akuntabilitas pengelolaan keuangan pemerintah, baik pemerintah pusat maupun pemerintah daerah adalah dengan menyampaikan laporan pertanggungjawaban berupa laporan keuangan.

Pengguna laporan keuangan berasal dari berbagai pihak dengan kepentingan yang berbedabeda. Pengguna laporan keuangan pemerintahan antara lain (PP 71 Tahun 2010): masyarakat, wakil rakyat, lembaga pengawas, lembaga pemeriksa, pihak yang memberi atau berperan dalam proses donasi, investasi dan pinjaman, serta pemerintah. Kegunaan atau kebermanfaatan (usefulness) dapat ditentukan secara kualitatif.

Untuk menciptakan sumber daya manusia aparatur yang memiliki kompetensi tersebut diperlukan peningkatan mutu profesionalisme, sikap pengabdian dan kesetiaan pada perjuangan bangsa dan negara, semangat kesatuan dan persatuan, dan pengembangan wawasan Pegawai Negeri Sipil. Oleh sebab itu, suatu instansi harus dapat meningkatkan kualitas sumber daya manusianya. Untuk meningkatkan

kualitas atau kemampuan-kemampuan pegawainya tersebut, dapat dilakukan melalui pendidikan dan pelatihan. Karena pendidikan dan pelatihan merupakan bagian tidak terpisahkan dari usaha pembinaan Pegawai Negeri Sipil secara menyeluruh.

Pengembangan pegawai sangat diperlukan dalam sebuah instansi, karena dengan adanya program tersebut dapat membantu meningkatkan kemampuan dan keterampilan pegawai. Pengembangan pegawai juga dirancang untuk memperoleh pegawaipegawai yang mampu berprestasi dan fleksibel untuk suatu instansi dalam geraknya ke masa depan. Pentingnya pendidikan dan pelatihan bukanlah semata-mata bagi pegawai yang bersangkutan, tetapi juga keuntungan organisasi. Karena dengan meningkatnya kemampuan atau keterampilan para pegawai, dapat meningkatkan produktivitas kerja para pegawai. Produktivitas kerja meningkat berarti organisasi yang bersangkutan akan memperoleh keuntungan (Notoadmodjo, 2003 dalam Muhammad Nur Khaliq, 2014). Pendidikan dan pelatihan juga merupakan upaya untuk mengembangkan kemampuan intelektual dan kepribadian pegawai. Oleh karena itu setiap organisasi atau instansi yang ingin berkembang, pendidikan dan pelatihan pegawainya harus memperoleh perhatian yang 
lebih besar sehingga dapat meningkatkan kinerja pegawainya tersebut (Notoatmodjo, 2003 dalam Muhammad Nur Khaliq, 2014).

Selain itu keterampilan (Skill) karyawan atau pegawai juga dapat diukur dengan lama masa kerja atau pengalaman kerjanya.

Pengalaman akan menentukan dalam melaksanakan suatu tugas tertentu. Menurut Nasarudin (2008) dalam Muhammad Nur Khaliq (2014) menyatakan bahwa "Pengalaman kerja membuat seseorang dapat meningkatkan pengetahuan teknis maupun keterampilan kerja dengan mengamati orang lain, menirukan dan melakukan sendiri tugas-tugas pekerjaan yang ditekuni. Dengan melakukan pekerjaan secara berulang-ulang, seseorang akan lebih mahir dalam melaksanakan tugasnya dan terbuka peluang untuk memperoleh cara kerja yang lebih praktis, produktif dan efisien".

Kewajiban pemanfaatan teknologi informasi oleh Pemerintah dan Pemerintah Daerah diatur dalam Peraturan Pemerintah No.

56 Tahun 2005 tentang Sistem Informasi Keuangan Daerah yang merupakan pengganti dari PP No. 11 Tahun 2001 tentang Sistem Informasi Keuangan Daerah.

Walaupun secara umum telah banyak diketahui manfaat yang ditawarkan oleh suatu teknologi informasi antara lain kecepatan pemrosesan transaksi dan penyiapan laporan, keakuratan perhitungan, penyimpanan data dalam jumlah besar, kos pemrosesan yang lebih rendah, kemampuan multiprocessing, namun pengimplementasian teknologi informasi tidaklah murah. Terlebih jika teknologi informasi yang ada tidak atau belum mampu dimanfaatkan secara maksimal maka implementasi teknologi menjadi sia-sia dan semakin mahal. Kendala penerapan teknologi informasi antara lain berkaitan dengan kondisi perangkat keras, perangkat lunak yang digunakan, pemutakhiran data, kondisi sumber daya manusia yang ada, dan keterbatasan dana. Kendala ini yang mungkin menjadi faktor pemanfaatan teknologi informasi di instansi pemerintah belum optimal.

Bentuk laporan pertanggungjawaban atas pengelolaan keuangan daerah selama satu tahun anggaran adalah dalam bentuk Laporan Keuangan Pemerintah Daerah (LKPD). Laporan keuangan pemerintah daerah harus mengikuti Standar Akuntansi Pemerintahan sesuai Peraturan Pemerintah No.24 Tahun 2005. Tujuan diberlakukannya hal tersebut adalah agar lebih accountable dan semakin diperlukannya peningkatan kualitas laporan keuangan. Kualitas laporan keuangan pemerintah sangat dipengaruhi oleh faktor kepatuhan terhadap standar akuntansi, kapabilitas sumber daya manusia, serta dukungan sistem akuntansi yang ada. Tidak pula terlepas dinamika perubahan eksternal yang tidak dapat dikendalikan oleh organisasi. Laporan keuangan pemerintah kemudian disampaikan kepada DPR/DPRD dan masyarakat umum setelah diaudit oleh Badan Pemeriksa Keuangan (BPK). Adapun 
komponen laporan keuangan yang disampaikan tersebut meliputi Laporan Realisasi Anggaran, Neraca, Laporan Arus Kas, dan Catatan atas Laporan Keuangan. Governmental Accounting Standard Board dalam Concepts Statement No.1 tentang Objectives of Financial Reporting menyatakan bahwa akuntabilitas merupakan dasar pelaporan keuangan di pemerintahan. Pengelolaan keuangan pemerintah daerah harus dilakukan berdasarkan tata kelola kepemerintahan yang baik (good governance government), yaitu pengelolaan keuangan yang dilakukan secara transparan dan akuntabel, yang memungkinkan para pemakai laporan keuangan untuk dapat mengakses informasi tentang hasil yang dicapai dalam penyelenggaraan pemerintahan daerah.

\section{KAJIAN PUSTAKA, KERANGKA PEMIKIRAN, DAN HIPOTESIS Laporan Keuangan Pemerintah (LKP)}

Akuntansi keuangan sektor publik terkait dengan tujuan dihasilkannya laporan keuangan pemerintah (LKP). Pada dasarnya LKP adalah asersi dari pihak manajemen pemerintah yang menyajikan informasi yang berguna untuk pengambilan keputusan dan untuk menunjukkan akuntabilitas entitas pelaporan atas sumber daya yang dipercayakan kepadanya. Laporan keuangan digunakan untuk membandingkan realisasi pendapatan, belanja, transfer, dan pembiayaan dengan anggaran yang telah ditetapkan, menilai kondisi keuangan, mengevaluasi efektivitas dan efisiensi suatu entitas pelaporan, dan membantu menentukan ketaatannya terhadap peraturan perundang-undangan.
Berdasarkan Peraturan Pemerintah Nomor 71 tentang Standar Akuntansi Pemerintahan (SAP), Komponen-komponen yang terdapat dalam satu set laporan keuangan berbasis akrual terdiri dari laporan pelaksanaan anggaran (budgetary reports) dan laporan finansial, yang jika diuraikan adalah sebagai berikut:

1. Laporan Realisasi Anggaran

2. Laporan Realisasi Anggaran

3. Laporan Operasional

4. Laporan Perubahan Saldo Anggaran Lebih

5. Laporan Perubahan Ekuitas

6. Neraca

7. Laporan Arus Kas

8. Catatan atas Laporan Keuangan

\section{Pemerintah Daerah}

Pemerintah Daerah Berdasarkan PP 58 Tahun 2005 Tentang Pengelolaan Keuangan

Daerah, pemerintah daerah adalah penyelenggara pemerintahan daerah menurut asas otonomi dan tugas pembantuan dengan prinsip otonomi seluas-luasnya dalam sistem dan prinsip Negara Kesatuan Republik Indonesia sebagaimana dimaksud dalam Undang-Undang Dasar 1945. Pemerintah daerah adalah Gubernur, Bupati atau Walikota, dan perangkat daerah sebagai unsur penyelenggara pemerintahan daerah. Hubungan wewenang antara pemerintah pusat dan pemerintah daerah provinsi, kabupaten, dan kota atau antara provinsi dan kabupaten dan kota, diatur undang-undang dengan memperhatikan kekhususan dan keragaman daerah. 
Penyelenggaraan fungsi pemerintahan daerah akan terlaksana secara optimal apabila penyelenggaraan urusan pemerintahan diikuti dengan pemberian sumber-sumber penerimaan yang cukup kepada daerah, dengan mengacu

kepada undang-undang yang mengatur perimbangan keuangan antara pemerintah pusat dan pemerintahan daerah, dimana besarnya disesuaikan dan diselaraskan dengan pembagian kewenangan antara pemerintah dan daerah.

\section{Pendidikan dan Pelatihan}

Pendidikan menurut Kamus Besar Bahasa Indonesia, pendidikan diartikan sebagai proses pembelajaran bagi individu untuk mencapai pengetahuan dan pemahaman yang lebih tinggi mengenai objek-objek tertentu dan spesifik. Istilah pendidikan digunakan untuk menyadarkan pemakai informasi tentang informasi yang dapat dihasilkan oleh sistem dan berbagai persyaratan yang ditetapkan oleh pemakai yang dapat dipenuhi oleh sistem akuntansi yang dirancang.

Menurut Gomes (1997) dalam Anugeraheni Dyah Nastiti (2013) yang dimaksud dengan pelatihan kerja adalah setiap usaha untuk memperbaiki prestasi kerja pada suatu pekerjaan tertentu yang sedang menjadi tanggung jawabnya. Idealnya, pelatihan harus dirancang untuk mewujudkan tujuan-tujuan organisasi, yang pada waktu bersamaan juga mewujudkan tujuan-tujuan para pekerja secara perseorangan. Pelatihan kerja ditujukan kepada karyawan yang akan mengoperasikan sistem akuntansi. Karyawan yang mengoperasikan sistem terdiri dari karyawan yang bertugas untuk menyiapkan masukan, mengolah data, dan mengoperasikan dan menjaga komponen fisik dan logis sistem akuntansi.

\section{Pengalaman Kerja}

Elaine B Johnson (2007: 228) menyatakan bahwa "Pengalaman memunculkan potensi seseorang. Potensi penuh akan muncul bertahap seiring berjalannya waktu sebagai tanggapan terhadap bermacammacam pengalaman". Jadi sesungguhnya yang penting diperhatikan dalam hubungan tersebut adalah kemampuan seseorang untuk belajar dari pengalamannya, baik pegalaman manis maupun pahit. Maka pada hakikatnya pengalaman adalah pemahaman terhadap sesuatu yang dihayati dan dengan penghayatan serta mengalami sesuatu tersebut diperoleh pengalaman, ketrampilan ataupun nilai yang menyatu pada potensi diri.

Orang yang berpengalaman dalam bekerja memiliki kemampuan kerja yang lebih baik dari orang yang baru saja memasuki dunia kerja, karena orang tersebut telah belajar dari kegiatankegiatan dan permasalahan yang timbul dalam kerjanya. Dengan adanya pengalaman kerja maka telah terjadi proses penambahan ilmu pengetahuan dan ketrampilan serta sikap pada diri seseorang, sehingga dapat menunjang dalam mengembangkan diri dengan perubahan yang ada.

\section{Pemanfaatan Teknologi Informasi}

Menurut Bambang Warsita (2008:135)

teknologi informasi adalah sarana dan prasarana 
(hardware, software, useware) sistem dan metode untuk memperoleh, mengirimkan, mengolah, menafsirkan, menyimpan, mengorganisasikan, dan menggunakan data secara bermakna. Hamzah B. Uno dan Nina Lamatenggo (2010:57) juga mengemukakan teknologi informasi adalah suatu teknologi yang digunakan untuk mengolah data.

Definisi teknologi informasi menurut Darwanis \& Mahyani (2009) dalam (Siti Soimah, 2014) dalam penelitiannya adalah teknologi yang mempunyai kemampuan sedemikian rupa untuk menangkap (capture), menyimpan (store), mengolah (process), mengambil kembali (retrieve), menampilkan (represent) dan

menyebarkan

(transmit) informasi.

Pengembangan sistem informasi yang sesuai

memerlukan perpaduan dari berbagai pengetahuan tentang sistem komputer, sistem informasi dan pengetahuan tentang bagaimana merancang dan menerapkan sebuah sistem informasi serta bagaimana memperoleh sistem komputer yang diperlukan.

\section{Kinerja Keuangan}

Informasi akan bermanfaat kalau informasi tersebut dapat mendukung pengambilan keputusan dan andal (Ariesta, 2013). Arfianti (2011) juga mengemukakan bahwa, informasi yang bermanfaat bagi para pemakai adalah informasi yang mempunyai nilai. Agar informasi tersebut dapat mendukung dalam pengambilan keputusan dan dapat dipahami oleh para pemakai, maka informasi akuntansi harus mempunyai beberapa karakteristik kualitatif yang diisyaratkan. Karakteristik kualitatif laporan keuangan adalah ukuran-ukuran normatif yang perlu diwujudkan dalam informasi akuntansi sehingga dapat memenuhi tujuannya. Adapun karakteristik kualitatif laporan keuangan pemerintah yang memenuhi kualitas yang dikehendaki antara lain (Peraturan Pemerintah Nomor 71 Tahun 2010): 1) Relevan, 2) Andal, 3) Dapat dibandingkan, 4) Dapat dipahami.

\section{Hipotesis}

Hipotesis merupakan jawaban sementara dari pokok permasalahan penelitian yang akan diuji sebenarnya. Berdasarkan pada rumusan permasalahan, tujuan penelitian, dan kajian teori yang relevan ataupun hasil penelitian sebelumnya, maka hipotesis dalam penelitian adalah:

$\mathrm{H}_{1}=$ Pendidikan dan pelatihan berpengaruh signifikan terhadap kualitas laporan keuangan pemerintah daerah.

$\mathrm{H}_{2}=$ Pengalaman kerja berpengaruh signifikan terhadap kualitas laporan keuangan pemerintah daerah.

$\mathrm{H}_{3}=$ Pemanfaatan teknologi informasi berpengaruh signifikan terhadap kualitas laporan keuangan pemerintah daerah.

\section{OBJEK DAN METODOLOGI PENELITIAN}

Penelitian ini dilakukan dengan menggunakan pendekatan kuantitatif. Metode penelitian kuantitatif merupakan metode penelitian yang berlandaskan pada filsafat, 
digunakan untuk meneliti pada populasi atau sampel tertentu, pengumpulan data menggunakan instrumen penelitian, analisis data bersifat kuantitatif atau statistik, dengan tujuan menguji hipotesis yang telah ditetapkan (Sugiyono, 2010). Obyek penelitian ini adalah pegawai keuangan di SKPD kota Depok.

\section{Operasionalisasi Variabel}

Operasionalisasi variabel adalah variabelvariabel yang digunakan dalam penelitian dan menunjukkan cara pengukuran dari masing-masing variabel tersebut. Berikut merupakan variabelvariabel yang digunakan dalam penelitian ini yaitu:

\section{Pendidikan dan Pelatihan}

Pendidikan menurut Kamus Besar Bahasa Indonesia, pendidikan diartikan sebagai proses pembelajaran bagi individu untuk mencapai pengetahuan dan pemahaman yang lebih tinggi mengenai objek-objek tertentu dan spesifik. Pengetahuan tersebut diperoleh secara formal yang berakibat individu mempunyai pola pikir dan perilaku sesuai dengan pendidikan yang diperolehnya.

Menurut Gomes (1997) dalam Anugeraheni Dyah Nastiti (2013) yang dimaksud dengan pelatihan kerja adalah setiap usaha untuk memperbaiki prestasi kerja pada suatu pekerjaan tertentu yang sedang menjadi tanggung jawabnya.

\section{Pengalaman Kerja}

Elaine B Johnson (2007: 228) menyatakan bahwa "pengalaman memunculkan potensi seseorang.
Potensi penuh akan muncul bertahap seiring berjalannya waktu sebagai tanggapan terhadap bermacammacam pengalaman”. Jadi sesungguhnya yang penting diperhatikan dalam hubungan tersebut adalah kemampuan seseorang untuk belajar dari pengalamannya, baik pegalaman manis maupun pahit. Maka pada hakikatnya pengalaman adalah pemahaman terhadap sesuatu yang dihayati dan dengan penghayatan serta mengalami sesuatu tersebut diperoleh pengalaman, ketrampilan ataupun nilai yang menyatu pada potensi diri.

\section{Pemanfaatan Teknologi Informasi}

Menurut Bambang Warsita (2008:135) teknologi informasi adalah sarana dan prasarana (hardware, software, useware) sistem dan metode untuk memperoleh, mengirimkan, mengolah, menafsirkan, menyimpan, mengorganisasikan, dan menggunakan data secara bermakna. Hamzah B. Uno dan Nina Lamatenggo (2010:57) juga mengemukakan teknologi informasi adalah suatu teknologi yang digunakan untuk mengolah data.

\section{Kualitas Laporan Keuangan Pemerintah Daerah}

Kualitas Laporan Keuangan Pemerintah Daerah, yaitu kemampuan informasi yang disajikan dalam laporan keuangan dapat dipahami, dan memenuhi kebutuhan pemakainya dalam pengambilan keputusan, 
bebas dari pengertian yang menyesatkan, kesalahan material serta dapat diandalkan, sehingga laporan keuangan tersebut dapat dibandingkan dengan periode-periode sebelumnya.

Variabel kualitas laporan keuangan pemerintah daerah dilihat dari karakteristik kualitatif laporan keuangan berdasarkan PP No. 71 Tahun 2010 yaitu: relevan, andal, dapat dibandingkan dan dapat dipahami.

\section{Rancangan Analisis}

\section{Analisis Statistik Deskriptif}

Menurut Sugiyono (2009) penelitian deskriptif yaitu penelitian yang dilakukan untuk mengetahui nilai variabel mandiri, baik satu variabel atau lebih (independen) tanpa membuat perbandingan atau menghubungkan dengan variabel lain. Dapat disimpulkan bahwa metode deskriptif adalah metode yang bertujuan untuk menghasilkan gambaran mengenai mekanisme sebuah hubungan.

\section{Uji Validitas}

Uji validitas digunakan untuk mengukur sah atau valid tidaknya suatu kuesioner. Suatu kuesioner dikatakan valid jika pertanyaan pada kuesioner mampu untuk mengungkapkan sesuatu yang diukur oleh kuesioner tersebut. Teknik yang digunakan untuk melakukan uji validitas adalah dengan menggunakan koefisien korelasi Pearson correlation. Data dikatakan valid apabila korelasi antar skor masing-masing butir pertanyaan dengan total skor setiap konstruknya signifikan pada level
0,05 atau 0,01 maka pertanyaan tersebut dikatakan valid (Ghozali, 2011).

\section{Uji Realibilitas}

Uji reliabilitas dimaksudkan untuk mengukur suatu kuesioner yang merupakan indikator dari variabel. Suatu kuesioner dikatakan reliable atau handal jika jawaban seseorang terhadap pertanyaan adalah konsisten atau stabil dari waktu ke waktu. Uji reliabilitas diukur dengan uji statistik Cronbach's Alpha (a), yaitu suatu variabel dikatakan reliable jika memberikan nilai Cronbach's Alpha > 0.70 (Nunnally, 1994 dalam Ghozali, 2011).

\section{Uji Normalitas Data}

Uji normalitas bertujuan untuk menguji apakah dalam model regresi, variabel pengganggu atau residual memiliki distribusi normal (Ghozali, 2011). Uji normalitas yang digunakan yaitu kolmograv-smirnov dengan menggunakan taraf signifikan 0,05. Dasar penarikan kesimpulan adalah data dikatakan berdistribusi normal apabila $\rho_{\text {-kolmogravsmrinov test }>0,05}$ (Ghozali, 2011).

\section{Uji Multikolinearitas}

Uji multikolinearitas bertujuan untuk menguji apakah dalam model regresi ditemukan adanya kolerasi antara variabel bebas (independen). Model regresi yang baik seharusnya tidak terjadi korelasi diantara variabel independen. Uji Multikolinearitas dapat dilihat dari besarnya nilai VIF (Variance Inflation Factors) dan nilai toleransi. Jika nilai toleransi 
$>0,10$ atau sama dengan nilai VIF $<10$, artinya tidak ada korelasi antar variabel bebas atau tidak terjadi multikolinieritas antar variabel bebas (Ghozali, 2011).

\section{Uji Heterokedastisitas}

Uji Heteroskedastisitas ini memiliki tujuan untuk menguji apakah dalam model terjadi kesamaan varian dari residual satu pengamatan ke pengamatan yang lain atau untuk melihat penyebaran data. Jika varian dari residual satu ke pengamatan yang lain tetap, maka disebut homokedastisitas dan jika berbeda disebut heteroskedastisitas. Model regresi yang baik adalah tidak terdapat heteroskedastisitas. Uji ini dilakukan dengan metode korelasi Spearman's rho yaitu mengkorelasikan variabel independen dengan nilai unstandarized residual.

\section{Uji Koefesien Determinasi}

Koefisien determinasi $\left(\mathrm{R}^{2}\right)$ mengukur seberapa besar kemampuan model dalam menerangkan variasi variabel dependen. Nilai $\mathrm{R}^{2}$ adalah diantara nol dan satu. Nilai $\mathrm{R}^{2}$ yang kecil menunjukkan kemampuan variabelvariabel independen dalam menjelaskan variasi variabel dependen amat terbatas. Jika nilai $\mathrm{R}^{2}$ mendekati satu maka variabel-variabel independen memberikan hampir semua informasi yang dibutuhkan untuk memprediksi variasi variabel dependen. Penelitian ini menggunakan Adjusted-R2 karena nilai Adjusted-R2 dapat naik atau turun apabila suatu variabel independen ditambahkan ke dalam model. Semakin tinggi nilai Adjusted-
$R 2$ maka semakin tinggi variabel independen dapat menjelaskan variasi variabel dependen (Ghozali, 2011).

\section{Uji Simultan (F-test)}

Uji statistik $F$ pada dasarnya menunjukkan apakah semua variabel independen yang dimasukan dalam model mempunyai pengaruh secara bersama-sama atau simultan terhadap variabel dependen (Ghozali, 2011). Dengan tingkat signifikan sebesar 5\% $(\alpha=0,05)$.

\section{Uji Statistik t (t-test)}

Pengujian hipotesis dilakukan dengan uji regresi secara parsial (uji t). uji statistik t pada dasarnya untuk mengetahui pengaruh satu variabel independen secara individual dalam menerangkan variabel dependen secara signifikan. Jika probabilitas sig. < 0,05 maka variabel independen secara individual mempengaruhi variabel dependen (Ghozali, 2011).

\section{PEMBAHASAN}

\section{Statisk Deskriptif}

Statistik deskriptif dapat memberikan gambaran tentang suatu data yang dilihat dari nilai minimum, maksimum, rata-rata (mean), standart deviasi dan variance yang dihasilkan dari variabel penelitian. Variabel-variabel yang digunakan dalam penelitian ini meliputi Pendidikan dan Pelatihan, Pengalaman Kerja, serta Pemanfaatan Teknologi Informasi. Deskripsi dari masing-masing pertanyaan dari kuesioner tersebut akan diuji secara statistik 
deskriptif dengan menggunakan program SPSS seperti yang terlihat dalam tabel 4.1 berikut ini:

Tabel 1

\section{Hasil Statistik Deskriptif Jawaban}

\section{Responden}

\begin{tabular}{|c|c|c|c|c|c|c|}
\hline $\begin{array}{c}\text { Nama } \\
\text { Variabel }\end{array}$ & $\mathbf{N}$ & $\begin{array}{l}\text { Kisaraas } \\
\text { Teoritis }\end{array}$ & $\begin{array}{l}\text { Kisaran } \\
\text { Alksual }\end{array}$ & $\begin{array}{l}\text { Meam } \\
\text { Teoritin }\end{array}$ & $\begin{array}{l}\text { Mesw } \\
\text { Aktual }\end{array}$ & $\begin{array}{c}\text { Srd } \\
\text { Deviafion }\end{array}$ \\
\hline $\begin{array}{l}\text { Pendidikan } \\
\text { dan Pelatitian }\end{array}$ & 55 & $10-50$ & $29-50$ & 30 & 40,78 & 5,136 \\
\hline $\begin{array}{l}\text { Pengalanian } \\
\text { Kerja }\end{array}$ & $\$ 5$ & $8-40$ & 16.39 & 24 & 29,06 & 5,072 \\
\hline $\begin{array}{l}\text { Pemanfatan } \\
\text { Teknologi } \\
\text { Informani }\end{array}$ & 55 & $9-45$ & $27-45$ & 27 & 36,55 & 4,436 \\
\hline $\begin{array}{c}\text { Kualitas } \\
\text { Laporan } \\
\text { Kevangan } \\
\text { Pemerintah } \\
\text { Daerah }\end{array}$ & 55. & $10-50$ & $29-50$ & 30 & 40,84 & 4,459 \\
\hline
\end{tabular}

Sumber: Data Diolah Penulis, Tahun 2018

Data Tabel 1 di atas dapat diketahui informasi tentang standar deviasi, ratarata, serta rentang teoritis masing-masing pertanyaan dan rentang aktual dari masingmasing responden. Berdasarkan Tabel 1 disajikan hasil; statistik deskriptif tentang variabel-variabel penelitian sebagai berikut:

1. Pendidikan dan pelatihan

Variabel pendidikan dan pelatihan diukur dengan menggunakan instrumen yang terdiri dari 10 pertanyaan. Seperti terlihat pada Tabel 1, dari 55 responden dihasilkan rentang aktual 29-50, artinya tingkat pendidikan dan pelatihan yang rendah berada pada kisaran 29 dan tingkat pendidikan dan pelatihan yang lebih tinggi berada pada kisaran 50, sedangkan rentang yang mungkin terjadi adalah antara 10 (menunjukan pendidikan dan pelatihan yang paling rendah) sampai 50 (menunjukan pendidikan dan pelatihan yang paling tinggi). Sedangkan untuk mean teoritis adalah 30 dan mean aktual sebesar 40,78. Hal ini mengindikasi bahwa pendidikan dan pelatihan yang didapatkan para pegawai pengelola keuangan dari lembaga pemerintah kota Depok semakin besar.

2. Pengalaman Kerja

Variabel pengalaman kerja diukur dengan menggunakan instrumen yang terdiri dari 8 pertanyaan. Seperti terlihat pada Tabel 1, dari 55 responden dihasilkan rentang aktual 16-39, artinya tingkat pengalaman kerja yang rendah berada pada kisaran 16 dan tingkat pengalaman kerja yang lebih tinggi berada pada kisaran 39, sedangkan rentang yang mungkin terjadi adalah antara 8 (menunjukan pengalaman kerja yang paling rendah) sampai 40 (menunjukan pengalaman kerja yang paling tinggi). Sedangkan untuk mean teoritis adalah 24 dan mean aktual sebesar 29,96. Hal ini mengindikasi bahwa pengalaman kerja yang dimiliki para pegawai pengelola keuangan di pemerintahan kota Depok semakin besar atau semakin berpengalaman.

3. Pemanfaatan Teknologi Informasi Variabel pemanfaatan teknologi informasi diukur dengan menggunakan 
instrumen yang terdiri dari 9 pertanyaan. Seperti terlihat pada Tabel 1, dari 55 responden dihasilkan rentang aktual 27-

45, artinya tingkat pemanfaatan teknologi informasi yang rendah berada pada kisaran 27 dan tingkat pemanfaatan teknologi informasi yang lebih tinggi berada pada kisaran 45, sedangkan rentang yang mungkin terjadi adalah antara 9 (menunjukan pemanfaatan teknologi informasi yang paling rendah) sampai 45 (menunjukan pemanfaatan teknologi informasi yang paling tinggi). Sedangkan untuk mean teoritis adalah 27 dan mean aktual sebesar 36,55. Hal ini mengindikasi bahwa pemanfaatan teknologi informasi yang digunakan para pegawai pengelola keuangan di pemerintahan kota Depok semakin besar.

4. Kualitas Laporan Keuangan Pemerintah Daerah

Variabel kualitas lapoan keuangan pemerintah daerah diukur dengan menggunakan instrumen yang terdiri dari 10 pertanyaan. Seperti terlihat pada tabel 4.1, dari 55 responden dihasilkan rentang aktual 29-50, artinya tingkat kualitas laporan keuangan pemerintah daerah yang rendah berada pada kisaran 29 dan tingkat kualitas laporan keuangan pemerintah daerah yang lebih tinggi berada pada kisaran 50, sedangkan rentang yang mungkin terjadi adalah antara 10 (menunjukan kualitas laporan keuangan pemerintah daerah yang paling rendah) sampai 50 (menunjukan kualitas laporan keuangan pemerintah daerah yang paling tinggi). Sedangkan untuk mean teoritis adalah 30 dan mean aktual sebesar 40,84. Hal ini mengindikasi bahwa kualitas laporan keuangan pemerintah daerah yang dihasilkan para pegawai pengelola keuangan di pemerintahan kota Depok semakin besar.

\section{Hasil Uji Validitas}

Uji validitas digunakan untuk mengukur valid atau tidaknya kuesioner yang digunakan. Teknik yang digunakan untuk melakukan uji validitas adalah koefisien korelasi Pearson Correlation. Data dikatakan valid jika total setiap konstruknya signifikan pada level 0,05 atau 0,01. Hasil pengujian validitas dalam penelitian ini dapat terlihat pada Tabel 2,3, 4, dan 5 di bawah ini.

\section{Tabel 2}

\section{Hasil Uji Validitas Variabel Pendidikan dan Pelatihan}

\begin{tabular}{|c|c|c|c|}
\hline Pertanyaan & Pearson Correlation & Sig. (2-Tailed) & Keterangan \\
\hline 1 & 0,490 & 0,000 & Valid \\
\hline 2 & 0,480 & 0,000 & Valid \\
\hline 3 & 0,811 & 0,000 & Valid \\
\hline 4 & 0,745 & 0,000 & Valid \\
\hline 5 & 0,682 & 0,000 & Valid \\
\hline 6 & 0,712 & 0,000 & Valid \\
\hline 7 & 0,532 & 0,000 & Valid \\
\hline 8 & 0,438 & 0,000 & Valid \\
\hline 9 & 0,642 & 0,000 & Valid \\
\hline 10 & 0,621 & 0,000 & Valid \\
\hline
\end{tabular}

Sumber: Data Diolah Penulis, Tahun 2018

Hasil uji validitas diatas menunjukkan Pearson Correlation untuk variabel 
Pendidikan dan Pelatihan $\left(\mathrm{X}_{1}\right)$, signifikan pada tingkat signifikansi 0,05 atau 0,01 dan $\mathrm{r}$ hitung lebih besar dari pada $\mathrm{r}$ tabel, dimana dalam penlitian ini $\mathrm{r}$ tabel sebesar 0,266 atau 0,345 . Dengan demikian dapat disimpulkan bahwa semua pertanyaan dalam kuesioner mampu untuk mengukur variabel yang diharapkan.

\section{Tabel 3}

\section{Hasil Uji Validitas Variabel Pengalaman}

Kerja

\begin{tabular}{|c|c|c|c|}
\hline Pertanyaan & Pearson Correlation & Sig. (2-Tailed) & Keterangan \\
\hline 1 & 0,501 & 0,000 & Valid \\
\hline 2 & 0,427 & 0,001 & Valid \\
\hline 3 & 0,562 & 0,000 & Valid \\
\hline 4 & 0,603 & 0,000 & Valid \\
\hline 5 & 0,622 & 0,000 & Valid \\
\hline 6 & 0,500 & 0,000 & Valid \\
\hline 7 & 0,524 & 0,000 & Valid \\
\hline 8 & 0,356 & 0,008 & Valid \\
\hline
\end{tabular}

Sumber: Data Diolah Penulis, Tahun 2018

Hasil uji validitas diatas menunjukkan Pearson Correlation untuk variabel Pengalaman kerja $\left(\mathrm{X}_{2}\right)$, signifikan pada tingkat signifikansi 0,05 atau 0,01 dan $r$ hitung lebih besar dari pada $r$ tabel, dimana dalam penlitian ini $r$ tabel sebesar 0,266 atau 0,345. Dengan demikian dapat disimpulkan bahwa semua pertanyaan dalam kuesioner mampu untuk mengukur variabel yang diharapkan.

\section{Tabel 4}

\section{Hasil Uji Validitas Variabel Pemanfaatan Teknologi Informasi}

\begin{tabular}{|c|c|c|c|}
\hline Pertanyaan & Pearon Correlotion & Stg. (2-Tailed) & Keterangan \\
\hline 1 & 0,674 & 0,000 & Valid \\
\hline 2 & 0,721 & 0,000 & Valid \\
\hline 3 & 0,628 & 0,000 & Valid \\
\hline 4 & 0,602 & 0,000 & Valid \\
\hline 5 & 0,532 & 0,000 & Valid \\
\hline 6 & 0,523 & 0,000 & Valid \\
\hline 7 & 0,690 & 0,000 & Valid \\
\hline 8 & 0,514 & 0,000 & Valid \\
\hline 9 & 0,646 & 0,000 & Valid \\
\hline
\end{tabular}

Sumber: Data Diolah Penulis, Tahun 2018
Hasil uji validitas diatas menunjukkan Pearson Correlation untuk variabel Pemanfaatan Teknologi Informasi $\left(\mathrm{X}_{3}\right)$, signifikan pada tingkat signifikansi 0,05 atau 0,01 dan $r$ hitung lebih besar dari pada $r$ tabel, dimana dalam penlitian ini $r$ tabel sebesar 0,266 atau 0,345. Dengan demikian dapat disimpulkan bahwa semua pertanyaan dalam kuesioner mampu untuk mengukur variabel yang diharapkan.

\section{Tabel 5}

\section{Hasil Uji Validitas Variabel Kualitas}

\section{Laporan Keuangan Pemerintah Daerah}

\begin{tabular}{|c|c|c|c|}
\hline Pertasyaan & Peurson Correlation & Sig. (2-Tailed) & Keterangan \\
\hline 1 & 0,395 & 0,003 & Valid \\
\hline 2 & 0,539 & 0,000 & Valid \\
\hline 3 & 0,488 & 0,000 & Valid \\
\hline 4 & 0,653 & 0,000 & Valad \\
\hline 5 & 0,511 & 0,000 & Valid \\
\hline 6 & 0,589 & 0,000 & Valad \\
\hline 7 & 0,405 & 0,002 & Valid \\
\hline 8 & 0,435 & 0,001 & Valid \\
\hline 9 & 0,528 & 0,000 & Valid \\
\hline 10 & 0,589 & 0,000 & Valid \\
\hline
\end{tabular}

Sumber: Data Diolah Penulis, Tahun 2018

Hasil uji validitas diatas menunjukkan Pearson Correlation untuk variabel Kualitas Laporan Keuangan Pemerintah Daerah (Y), signifikan pada tingkat signifikansi 0,05 atau 0,01 dan $r$ hitung lebih besar dari pada $r$ tabel, dimana dalam penlitian ini $r$ tabel sebesar 0,266 atau 0,345. Dengan demikian dapat disimpulkan bahwa semua pertanyaan dalam kuesioner mampu untuk mengukur variabel yang diharapkan.

\section{Uji Realibiltas}

Uji reliabilitas diukur dengan uji statistik Cronbach's Alpha ( $\alpha$ ). Jika nilai Cronbach's

DOI: doi.org/10.21009/wahana-akuntansi/13.2.02 
Alpha > 0,70 maka data dikatakan reliabel. Hasil pengujian reliabilitas dalam penelitian ini dapat terlihat pada Tabel 6 berikut.

\section{Tabel 6}

\section{Hasil Uji Realibiltas}

\begin{tabular}{|c|c|c|}
\hline Nama Variabel & Cronbach's Alpha (a) & Keterangan \\
\hline didikan dan Pelatihan (XI) & 0,786 & Reliabel \\
\hline galaman $\mathrm{Kerja}(\mathrm{X} 2)$ & 0,523 & Reliabel \\
\hline $\begin{array}{l}\text { nanfaatan Teknologi lnfommasi } \\
\text { (X3) }\end{array}$ & 0,771 & Reliabel \\
\hline alitas Laporan Keuangan (Y) & 0,680 & Reliabel \\
\hline
\end{tabular}

Sumber: Data Diolah Penulis, Tahun 2018

Berdasarkan hasil pengujian reliabilitas pada tabel diatas, hasil perhitungan menunjukkan bahwa nilai Cronbach's Alpha

$(\alpha)$ untuk setiap variabel adalah lebih besar dari 0,70 atau alpha lebih besar daripada $r$ tabel, dimana dalam penelitian ini $r$ tabel sebesar 0,266 atau 0,345. Dalam realibiltas dibagi menjadi 4 kategori:

1. Jika alpha $>0,90$ maka realibiltas sempurna.

2. Jika alpha antara $0,70-0,90$ maka realibiltas tinggi.

3. Jika alpha antara $0,50-0,70$ maka realibilitas moderat

4. Jika alpha $<0,50$ maka realibiltas rendah.

Dengan demikian, dapat disimpulkan bahwa pertanyaan untuk masing-masing variabel dikatakan reliabel.

\section{Hasil Uji Normalitas Data}

Uji normalitas bertujuan untuk mengetahui apakah dalam model regresi, variabel independen dan variabel dependen mempunyai distribusi normal. Uji normalitas menggunakan Kolmograv-smirnov dengan nilai $\rho$-kolmograv-smirnov test $>0,05$ (Ghozali, 2011). Hasil pengujian normalitas dapat dilihat dalam Tabel 7 di bawah ini.

Tabel 7

\section{Hasil Uji Normalitas Data One-Sample} Kolmogorov-Smirnov Test

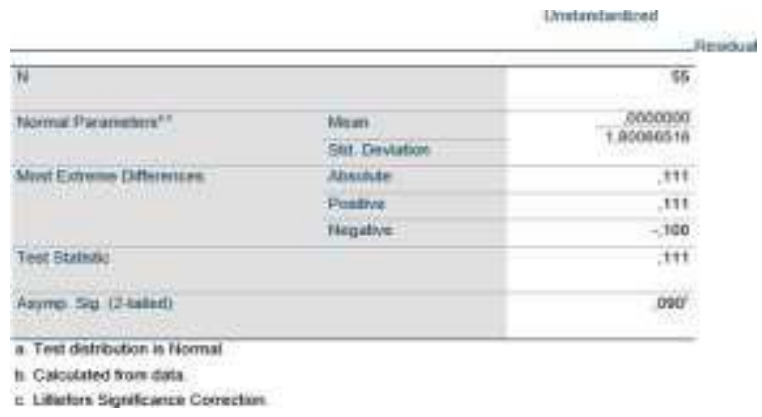

Sumber: Data Diolah Penulis, Tahun 2018

Tabel 7 di atas dapat disimpulkan bahwa seluruh variabel memiliki nilai keseluruhan Asymp. Sig. (2-tailed) >0,05, sehingga data yang digunakan dalam penelitian ini berdistribusi normal.

\section{Hasil Uji Heterokedastisitas}

Uji heteroskedastisitas digunakan untuk melihat apakah terjadi kesamaan varian dalam model dari residual satu pengamatan ke pengamatan lainnya. Uji heteroskedastisitas digunakan dengan metode Spearman. Model regresi dikatakan bebas dari heteroskedastisitas apabila probabilitas signifikansi variabel independen diatas 0,05 . 
Berdasarkan pengolahan data yang disajikan pada Tabel 8 di bawah ini, dapat dilihat hasil perhitungan nilai Sig. Dapat disimpulkan bahwa variabel independen memiliki nilai Sig. > 0,05, sehingga tidak terjadi Heterokedastisitas.

\section{Tabel 8}

\section{Hasil Uji Heteroskedastisitas}

\begin{tabular}{|l|c|c|}
\hline \multicolumn{1}{|c|}{ Nama Variabel } & Sig. & Keterangan \\
\hline didikan dan Pelatihan (X1) & 0,968 & $\begin{array}{c}\text { Tidak Terjadi } \\
\text { Heteroskedastisitas }\end{array}$ \\
\hline galaman Kerja (X2) & 0,108 & $\begin{array}{c}\text { Tidak Terjadi } \\
\text { Hereroskedastisitas }\end{array}$ \\
\hline $\begin{array}{l}\text { uanfatan Teknologi Informasi } \\
\text { (X3) }\end{array}$ & 0,056 & $\begin{array}{c}\text { Tidak Terjadi } \\
\text { Heteroskedastisitas }\end{array}$ \\
\hline
\end{tabular}

Sumber: Data Diolah Penulis, Tahun 2018

\section{Hasil Uji Multikolinearitas}

Uji multikolinearitas digunakan untuk mengetahui apakah dalam model regresi ditemukan adanya korelasi antar variabel bebas (independen). Uji ini dapat dilihat dari nilai VIF $<10$ dan toleransi > 0,10 maka tidak terjadi multikolinearitas (Ghozali, 2011). Hasil pengujian multikolinearitas dapat dilihat pada Tabel 9 di bawah ini.

Tabel 9

\section{Hasil Uji Multikolinearitas}

\begin{tabular}{|l|l|l|l|}
\hline Nama Variabel & Toletance & VIF & Keterangan \\
\hline $\begin{array}{l}\text { Pendidikan dan1 } \\
\text { Pelatiban (X1) }\end{array}$ & 0.900 & 1,111 & $\begin{array}{l}\text { Tidak Terjadi } \\
\text { Multikolinearitas }\end{array}$ \\
\hline $\begin{array}{l}\text { Pengalaman Kerja (X2) } \\
0,848\end{array}$ & $1,180$. & $\begin{array}{l}\text { Tidak Terjadi } \\
\text { Multikolinearitas }\end{array}$ \\
\hline $\begin{array}{l}\text { Pemanfaatan Teknologi } \\
\text { Informasi (X3) }\end{array}$ & 0,917 & 1,091 & $\begin{array}{l}\text { Tidak Terjadi } \\
\text { Multikolinearitas }\end{array}$ \\
\hline
\end{tabular}

Sumber: Data Diolah Penulis, Tahun 2018
Berdasarkan pengolahan data, dapat dilihat hasil perhitungan nilai Tolerance dan VIF. Dapat disimpulkan bahwa variabel independen memiliki nilai tolerance > 0,10, dan nilai $\mathrm{VIF}<10$, sehingga tidak terjadi multikolinearitas.

\section{Hasil Uji Hipotesis}

Untuk menguji pengaruh variabel independen yaitu, Pendidikan dan Pelatihan $\left(\mathrm{X}_{1}\right)$, Pengalaman Kerja $\left(\mathrm{X}_{2}\right)$, dan Pemanfaatan Teknologi Infromasi $\left(\mathrm{X}_{3}\right)$ terhadap variabel dependen yaitu, kualitas laporan keuangan pemerintah daerah (Y) digunakan model regresi berganda. Hasil olah data dengan bantuan SPSS 24 dapat terlihat pada tabel berikut :

\section{Tabel 10}

\section{Hasil Uji Hipotesis}

\begin{tabular}{|l|c|c|c|}
\hline \multicolumn{1}{|c|}{ Nama Variabel } & $\begin{array}{c}\text { Koefisisen } \\
\text { Regresi }\end{array}$ & t Statistilc & Sig. \\
\hline $\begin{array}{l}\text { Pendidikan dan } \\
\text { Pelatihan (X1) }\end{array}$ & 0,017 & 5,201 & 0,842 \\
\hline Pengalaman Kerja (X2) & $-0,120$ & $-1,103$ & 0,275 \\
\hline $\begin{array}{l}\text { Pemanfaatan Teknologi } \\
\text { Informasi (X3) }\end{array}$ & 0,552 & 5,618 & 0,000 \\
\hline Square & 0,387 & & \\
\hline j. R Square & 0,351 & \\
\cline { 1 - 1 } & 10,723 & & \\
\hline & 0,000 & \\
\hline
\end{tabular}

Sumber: Data Diolah Penulis, Tahun 2018

Berdasarkan Tabel 10 di atas, dapat dilihat bahwa F hitung sebesar 10,723 dengan angka signifikansi $=0,000$. Karena nilai signifikansi dari data analisis lebih kecil dari 0,05 maka dapat diartikan bahwa model penelitian ini adalah layak atau dapat digunakan untuk memprediksi pengaruh 
pendidikan dan pelatihan, pengalaman kerja serta pemanfaatan teknologi informasi secara simultan terhadap kualitas laporan keuangan pemerintah daerah.

Berdasarkan Tabel 10 diketahui bahwa nilai koefisien determinasi (adjusted $R$ square) sebesar 0,351, yang berarti bahwa $35,1 \%$ variasi besarnya kualitas laporan keuangan pemerintah daerah dapat dijelaskan oleh variasi pendidikan dan pelatihan, pengalaman kerja serta pemanfaatan teknologi. Sedangkan sisanya sebesar $64,9 \%$ dijelaskan oleh variabel lain diluar model penelitian.

Dari hasil analisis diatas, terlihat bahwa nilai koefisien dari variabel independen pendidikan dan pelatiha $\left(\mathrm{X}_{1}\right)$ bernilai positif yaitu 0,017 dengan nilai signifikan bernilai 0,842 (>0,05). Hal ini berarti bahwa hipotesis pertama yang menyatakan "pendidikan dan pelatihan berpengaruh signifikan terhadap kualitas laporan keuangan pemerintah daerah" ditolak. Dari hasil analisis tersebut menunjukkan bahwa Pendidikan dan Pelatihan tidak berpengaruh signifikan terhadap kualitas laporan keuangan Pemerintah Daerah Kabupaten Depok.

Nilai koefisien variabel Pengalaman Kerja $\left(\mathrm{X}_{2}\right)$ bernilai negatif sebesar $-0,120$ dengan nilai signifikan 0,275 atau nilai signifikan >0,05. Hal ini berarti bahwa

hipotesis pertama yang menyatakan "Pengalaman Kerja berpengaruh signifikan terhadap kualitas laporan keuangan pemerintah daerah" ditolak. Dari hasil analisis tersebut menunjukkan bahwa Pengalaman Kerja tidak berpengaruh signifikan terhadap Kualitas laporan keuangan Pemerintah Daerah Kabupaten Depok.

Hasil dari nilai koefisien variabel independen pemanfaatan teknologi informasi (X3) bernilai positif sebesar 0,552 dengan nilai signifikan 0,000 atau nilai signifikan $<0,05$. Hal ini berarti bahwa hipotesis pertama yang menyatakan "pemanfaatan teknologi informasi berpengaruh signifikan terhadap kualitas laporan keuangan pemerintah daerah" diterima. Dari hasil analisis tersebut, menunjukkan bahwa Pemanfaatan Teknologi Infromasi berpengaruh positif dan signifikan terhadap Kualitas laporan keuangan Pemerintah Daerah Kabupaten Depok.

\section{Pengaruh Pendidikan dan Pelatihan Terhadap Kualitas Laporan Keuangan Pemerintah Daerah}

Berdasarkan hasil pengujian hipotesis dapat disimpulkan bahwa pendidikan dan pelatihan tidak berpengaruh signifikan terhadap kualitas laporan keuangan pemerintah daerah. Hal ini disebabkan karena tidak semua pegawai yang memilki tingkat pendidikan yang tinggi, paham dan bisa menyelesaikan permasalahan dalam laporan keuangan daerah dan program yang diberikan oleh lembaga tidak selalu dapat memperbaiki kinerja yang buruk terhadap pegawai.

Hasil penelitian ini berbeda dengan hasil penelitian dari Jhon Fiesgrald wungow, Linda Lambey dan Winston Pontoh (2016) bahwa tingkat pendidikan tidak berpengaruh 
signifikan terhadap kualitas laporan keuangan pemerintah daerah sedangkan pelatihan berpengaruh positif dan signifikan terhadap kualitas laporan keuangan pemerintah daerah, dan juga berbeda dengan hasil penelitian Mukhlisul Muzahid (2014). Mukhlisul Muzahid (2014) menyatakan bahwa Tingkat pendidikan dan kualitas pelatihan berpengaruh secara bersamasama terhadap kualitas laporan keuangan.

\section{Pengaruh Pengalaman Kerja Terhadap} Kualitas Laporan Keuangan Pemerintah Daerah

Berdasarkan hasil pengujian hipotesis dapat disimpulkan bahwa pengalaman kerja tidak berpengaruh signifikan terhadap kualitas laporan keuangan pemerintah daerah. Hal ini disebabkan karena tidak semua pegawai sering melakukan pekerjaan yang sekarang menjadi tanggung jawabnya dan mengerjakan pekerjaan tanpa ada kesalahan.

Hal ini berbeda dengan penelitian Mukhlisul Muzahid (2014) yang menyatakan bahwa pengalaman kerja berpengaruh secara bersama-sama terhadap kualitas laporan keuangan pemerintah daerah dan juga dengan penelitian Galih Pratama Putra (2013) yang menyatakan bahwa pengalaman kerja secara parsial berpengaruh signifikan terhadap kualitas pelaporan keuangan.

Pengaruh Pemanfaatan Teknologi

Informasi Terhadap Kualitas Laporan

Keuangan Pemerintah Daerah
Berdasarkan hasil pengujian hipotesis dapat disimpulkan bahwa pemanfaatan teknologi informasi berpengaruh positif dan signifikan terhadap kualitas laporan keuangan pemerintah daerah. Hal ini disebabkan karena semua pegawai keuangan di SKPD kota depok telah menggunakan komputer untuk menginput data dan mengolah data secara sistematis sehingga data yang dihasilkan tepat waktu dan dapat diandalkan. Serta memanfaatkan jaringan internet sebagai penghubung dalam pengiriman informasi.

Hasil penelitian ini sesuai dengan Penelitian Irfan Ikhwanul Haza (2015) yang menyatakan bahwa pemanfaatan teknologi berpengaruh terhadap kualitas laporan keuangan. Hasil penelitian Siti Soimah (2014) juga menyatakan bahwa pemanfaatan teknologi informasi berpengaruh terhadap kualitas laporan keuangan.

\section{KESIMPULAN DAN SARAN}

Kesimpulan

Penelitian ini bertujuan untuk mengetahui pengaruh Pendidikan dan Pelatihan, Pengalaman Kerja, serta Pemanfaatan Teknologi Informasi Terhadap Kualitas Laporan Keuangan Pemerintah Daerah Kabupaten Depok. Berdasarkan hasil penelitian, maka kesimpulan dari penelitian ini dapat diuraikan sebagai berikut:

1. Pendidikan dan Pelatihan tidak berpengaruh signifikan terhadap kualitas laporan keuangan Pemerintah Daerah. 
Berdasarkan hasil data kuesioner yang telah diolah hal ini disebabkan karena tidak semua pegawai yang memilki tingkat pendidikan yang tinggi, paham dan bisa menyelesaikan permasalahan dalam laporan keuangan daerah dan program yang diberikan oleh lembaga tidak selalu dapat memperbaiki kinerja yang buruk terhadap pegawai.

2. Pengalaman Kerja tidak berpengaruh signifikan terhadap kualitas laporan keuangan Pemerintah Daerah. Berdasarkan hasil data kuesioner yang telah diolah hal ini disebabkan karena tidak semua pegawai sering melakukan pekerjaan yang sekarang menjadi tanggung jawabnya dan mengerjakan pekerjaan tanpa ada kesalahan.

3. Pemanfaatan Teknologi Informasi berpengaruh positif dan signifikan terhadap kualitas laporan keuangan Pemerintah Daerah. Berdasarkan hasil data kuesioner yang telah diolah hal ini disebabkan karena semua pegawai keuangan di SKPD kota depok telah menggunakan komputer untuk menginput data dan mengolah data secara sistematis sehingga data yang dihasilkan tepat waktu dan dapat diandalkan. Serta memanfaatkan jaringan internet sebagai penghubung dalam pengiriman informasi.

\section{Saran}

Berdasarkan hasil dari pembahasan dan kesimpulan yang diperoleh maka penulis memberikan saran sebagai berikut :

1. Bagi Pemerintah agar dapat meningkatkan kualitas pelatihan dan juga dapat memberikan pendidikan berkelanjutan terhadap para pegawai yang dianggap membutuhkan. Pendidikan berkelanjutan tidak hanya berupa pendidikan dibangku kuliah tetapi juga bisa seminar dan kursus sesuai kebutuhan para pegawai.

2. Bagi Pemerintah agar dapat memberikan tanggung jawab yang berbeda kepada setiap pegawai agar para pegawai dapat menambah pengalaman kerja mereka di semua bidang sehingga dapat meningkatkan profesionalitas dalam bekerja.

3. Bagi peneliti lain yang/ tertarik untuk meneliti judul yang sama, agar dapat memperluas sampel dan menambahkan variabel lain.

4. Penelitian ini masih terbatas pada pendidikan dan pelatihan, pengalaman kerja, pemanfaatan teknologi informasi terhadap kualitas laporan keuangan pemerintah daerah. Untuk penelitian selanjutnya dapat dilakukan perubahan variabel penelitian untutk menemukan variabel-variabel lain yang berpengaruh. 
5. Penelitian ini masih memiliki keterbatasan, yaitu pada metode penelitian yang dipakai. Untuk penelitian selanjutnya dapat dilakukan dengan berbagai macam metode, seperti wawancara langsung, metode survei lapangan, dan lain-lain.

\section{DAFTAR PUSTAKA}

Arfianti, Dita. (2011). Analisis Faktor-faktor yang Mempengaruhi Nilai Informasi Pelaporan Keuangan Pemerintah Daerah (Studi pada Satuan Kerja Perangkat Daerah di Kabupaten Batang). Skripsi. Universitas Diponegoro. Semarang.

Ariesta, Fadila. (2013). Pengaruh Kualitas Sumber Daya Manusia, Pemanfaatan Teknologi Informasi, dan Pengendalian Intern Akuntansi Terhadap Nilai

Informasi Pelaporan Keuangan Pemerintah Daerah (Studi Pada Satuan Kerja Perangkat Daerah di Kabupaten Pasaman Barat). Fakultas Ekonomi. Universitas Negeri Padang. Padang.

Nastiti, A.D. (2013). Pengaruh Pendidikan, Pelatihan Dan Pengalaman Kerja Terhadap Kualitas Penyajian Informasi Akuntansi. Jurnal Ekonomi. hal: 2-3

Bambang, Warsita. (2008). Teknologi Pembelajaran, landasan dan aplikasinya. Jakarta: Rineka Cipta.

Ghozali, Imam. (2011). Aplikasi Analisis Multivariat Dengan Program SPSS. Badan Penerbitan Universitas Diponegoro: Semarang.

Hamzah B. Uno dan Nina Lamatenggo. (2010). Teknologi Komunikasi dan Informasi Pembelajran. Jakarta: Bumi Akasara.
Hasbullah, (2011). Dasar-dasar Ilmu Pendidikan. Jakarta : PT. Gramedia Pustaka.

Haza, Irfan Ikhwanul. (2015). Pengaruh Pemanfaatan Teknologi Informasi dan Pengawasan Keuangan Daerah Terhadap Kualitas Laporan Keuangan Daerah. Jurnal Ekonomi. Volume 3. hal: 10-14

John, Elaine B. (2007). Contextual Teaching and Learning. Terjemahan Ibnu Setiawan. Bandung: MLC.

Kholiq, N.M. (2014). Persepsi Pegawai Negeri Sipil Atas Pengaruh Pendidikan Dan Pelatihan (DIKLAT) Serta Pengalaman Kerja Terhadap Kinerja Penyusu Laporan Keuangan Satuan Kerja Perangkat Daerah Di Kota Bengkulu. Skripsi. Program Sarjana Akuntans. Bengkulu:Universitas Bengkulu.

Mahmudi. (2010). Analisis Laporan Keuangan Pemerintah Daerah:Panduan Bagi Eksekutif, DPRD, dan Masyarakat Dalam Pengambilan Keputusan Ekonomi, Sosial dan Politik, Yogyakarta : Sekolah Tinggi Ilmu Manajemen YKPN.

Mondy, R. Wayne, (2008). Manajement Sumberdaya Manusia, Jilid 1 Edisi 10. Erlangga, Jakarta.

Muzahid, Mukhlisul. (2014). Pengaruh Tingkat Pendidikan, Kualitas Pelatihan, dan Lama Pengalaman Kerja Pegawai Terhadap Kualitas Laporan Keuangan Satuan Kerja Perangkat Daerah (SKPD) di Kabupatem Aceh Utara. Jurnal Ekonomi. Volume 2. hal: 12-16.

Peraturan Pemerintah No.24 Tahun 2005 Tentang Standar Akuntansi Pemerintahan.

Peraturan Pemerintah No. 56 Tahun 2005 tentang Sistem Informasi Keuangan Daerah yang merupakan pengganti dari PP No. 11 Tahun 2001 tentang Sistem Informasi Keuangan Daerah. 
Peraturan Pemerintah Nomor 58 Tahun 2005 Tentang Pengelolaan Keuangan Daerah.

Peraturan Pemerintah Nomor 71 Tahun 2010

Tentang Standar Akuntansi

Pemerintahan (SAP) Berbasis Akrual.

Putra, G.P. (2013). Pengaruh Faktor Pengalaman Kerja, Motivasi Kerja, dan Intensitas Pelatihan Terhadap Kualitas Pelaporan Keuangan Satuan Kerja di Wilayah Bayar KPPN Malang. Jurnal Ekonomi. Volume 1. hal: 6-9.

Sugiyono. (2010). Metode Penelitian Kuantitatif, Kualitatif \& RND. Bandung : Alfabeta.

Soimah, Siti. (2014). Pengaruh Kapasitas Sumber Daya Manusia, Pemanfaatan Teknologi Informasi, Sistem Pengendalian Intern Pemerintah Terhadap Kualitas Laporan Keuangan Pemerintah Daerah Kabupaten Bengkulu Utara. Skripsi. Program Sarjana Akuntansi. Bengkulu: Universitas Bengkulu.

Undang-Undang Nomor 17 Tahun 2003 tentang Keuangan Negara.

Undang-Undang Nomor 32 Tahun 2004 tentang Pemerintahan Daerah.

Undang-Undang Nomor 33 Tahun 2004 Tentang Sumber Pendapatan.

Wungow, J.F., Lambey,L., Pontoh,W. (2016). Pengaruh Tingkat Pendidikan, Masa Kerja, Pelatihan dan Jabatan Terhadap Kualitas Laporam Keuangan Pemerintah Kabupaten Minahasa Selatan. Jurnal Ekonomi. Volume 7. hal: 184-186.
Yosefrinaldi. (2013). Pengaruh Kapasitas Sumber Daya Manusia dan Pemanfaatan Teknologi Informasi Terhadap Kualitas Laporan Keuangan Pemerintah Daerah Dengan Variabel Intervening Sistem Pengendalian Intern Pemerintah (Studi Empiris Pada Dinas Pengelolaan Keuangan dan Aset Daerah Se-Sumatera Barat). Fakultas Ekonomi. Universitas Negeri Padang. Padang. 